4. Moskvychova, A. (2013). Try istorii pro ukrainskyi komiks [The three stories about Ukrainian comics]. Chytomo, 2013. Retrieved from: http://archive.chytomo.com/news/tri-istoriii-pro-ukraiinskij-komiks [in Ukrainian].

5. Literaturnaya enciklopediya terminov i ponyatij [Literary Encyclopedia of terms and concepts]. Glav. red. Nikolyukin A. Moskva: Intelvak, 2001. 1600 p. [in Russian].

6. Oliinyk, Ye. (2012). V Ukraini stvoryly komiks-blokbaster pro kozakiv [Ukraine has created a blockbuster comic book about the Cossacks]. Radio "Svoboda". Retrieved from: https:/www.radiosvoboda.org/a/24682040.html [in Ukrainian].

7. Pocheptsov, H. (2013). Komiksy yak zasib transliatsiï sotsialnykh smysliv [Comics as a means of broadcasting social meanings]. Merlin, Supermen i Harri Potter: konstruiuvannia nematerialnoho v masoviy kulturi. Kyiv: Spadshchyna, 2013. Pp. 39-48 [in Ukrainian].

8. Ukrainski komiksy u SShA spryinialy krashche, nizh v Ukraini - khudozhnyk [Ukrainian comics were received better in the United States than in Ukraine - the artist]. Retrieved from: https://www.radiosvoboda.org/a/28674397.html [in Ukrainian].

9. Filonenko, B. Potriyne "Os!", abo Dekilka pohliadiv na komiks-zhurnalistyku [Triple "Here!", or a few views on comic journalism]. Retrieved from: http://www.chytomo.com/book-art/potrijne-os-abo-dekilka-poglyadiv-na-komikszhurnalistiku [in Ukrainian].

10. Eko, U. (2005). Mif o supermene. Rol' chitatelya. Issledovaniya po semiotike teksta [The myth of Superman. The role of the reader. Researches on semiotics of the text]. Moskva, 2005. Retrieved from: http://culturca.narod.ru/eco1.htm [in Russian].

11. McCloud, S. (1994). Understanding Comics: The Invisible Art. New York: William Morrow Paperbacks, 1994.224 p. [in English].

12. McCloud, S. (2006). Making Comics. Storytelling Secrets of Comics, Manga and Graphics. New York: Harper, 2006. 264 p. [in English].

\title{
DOI https://doi.org/10.51647/kelm.2020.5.1.6
}

\section{LAND ART OBIEKTY Z METALU JAKO TREND SZTUKI WSPÓLCZESNEJ}

\author{
Olha Halchynska \\ aspirant Wydziatu Projektowania \\ Kijowskiego Narodowego Uniwersytetu Technologii i Projektowania (Kijów, Ukraina) \\ ORCID ID: 0000-0002-3030-6911 \\ ol_ga@meta.ua \\ Liliia Navolska \\ aspirant Wydziatu Projektowania \\ Kijowskiego Narodowego Uniwersytetu Technologii i Projektowania (Kijów, Ukraina) \\ ORCID ID: 0000-0002-0244-0371
}

\begin{abstract}
Adnotacja. Celem artykułu jest zbadanie sposobów zastosowania techniki druciarskiej, z której korzystają artyści przy tworzeniu obiektów land art. Podstawą metodologiczną badania jest podejście systemowe, metody analizy porównawczej i historycznej. Przeprowadzono analizę sposobów realizacji dzieł land art za pomocą techniki druciarskiej, które współcześni artyści wykorzystują w swoich pracach. Stwierdzono, że głównymi aspektami zastosowania techniki druciarskiej jest plastyczność, trwałość, odporność na wandalizm i użyteczność materiałów. Zbadano sposoby zastosowania techniki druciarskiej i koncepcji tworzenia obiektów artystycznych poprzez nadanie dziełu własnego składnika merytorycznego, określono kreatywne podejścia do tworzenia obiektów artystycznych.

Nowością naukową jest badanie autorskich technik artystycznych i cech tworzenia obiektów land art z wykorzystaniem techniki druciarskiej.

Znaczenie praktyczne polega na usystematyzowaniu sposobów tworzenia obiektów land art wykonanych techniką druciarską. Materiały przedstawione w artykule mogą być wykorzystane w badaniach naukowych poświęconych sztuce land art na Ukrainie i na świecie, popularyzacji tradycyjnych technik sztuki użytkowej, oraz do dalszego wdrażania autorskich projektów artystycznych.
\end{abstract}

Słowa kluczowe: projektowanie, sztuka, ekologia, projektowanie ekologiczne, kultura, projekty kreatywne. 


\title{
LAND ART OBJECTS ARE MADE OF METAL AS A TREND OF MODERN ART
}

\author{
Olga Galchynska \\ Postgraduate Student at the Faculty of Design \\ Kyiv National University of Technologies and Design (Kyiv, Ukraine) \\ ORCID ID: 0000-0002-3030-6911 \\ ol_ga@meta.ua \\ Liliia Navolska \\ Postgraduate Student at the Faculty of Design \\ Kyiv National University of Technologies and Design (Kyiv, Ukraine) \\ ORCID ID: 0000-0002-0244-0371
}

\begin{abstract}
The purpose of the article is to research the methods of application of the wire-weaving technique ("drotarstvo") used by the artists in the creation of Land Art objects. The methodological basis of the study is a systematic approach, methods of historical and comparative analysis, as well as art history analysis. The analysis of the methods of realization of Land Art objects made by means of the wire-weaving technique, which are used by the modern artists in their works, is carried out. It is found that the main aspects of the use of the wire-weaving technique are plasticity, durability, vandal resistance, and ease of use of materials. The methods of use of the wire-weaving technique and the concept of creation of art objects by giving the work its semantic components are researched; the creative approaches to the creation of art objects are determined.

The scientific novelty lies in the study of the author's artistic techniques and features of the creation of Land Art objects using the wire-weaving technique.

Practical significance is realized in the systematization of the methods of creation of Land Art objects, made by means of the wire-weaving technique. The materials represented in the article can be used in scientific research on the Land Art in Ukraine and the world, the promotion of the traditional techniques of decorative and applied arts, as well as for further implementation in the author's art projects.
\end{abstract}

Key words: design, art, ecology, ecodesign, culture, creative projects.

\section{ЛЕНД-АРТ-ОБ'ЄКТИ З МЕТАЛУ ЯК ТЕНДЕНЦІЯ СУЧАСНОГО МИСТЕЦТВА}

\author{
Ольга Гальчинська \\ аспірантка факультету дизайну \\ Київського національного університету технологій та дизайну (Київ, Україна) \\ ORCID ID: 0000-0002-3030-6911 \\ ol_ga@meta.ua \\ Лілія Навольська \\ аспірантка факультету дизайну \\ Київського національного університету технологій та дизайну (Київ, Україна) \\ ORCID ID: 0000-0002-0244-0371
}

\begin{abstract}
Анотація. Метою статті є дослідження способів застосування техніки «дротарство», яку використовують митці під час створення об'єктів ленд-арту. Методологічною основою дослідження є системний підхід, методи порівняльно-історичного та мистецтвознавчого аналізу. Проведено аналіз способів реалізації творів ленд-арту за технікою дротарства, що використовують у своїх творах сучасні митці. Встановлено, що основними аспектами застосування техніки дротарства $є$ пластичність, довговічність, вандалостійкість та зручність використання матеріалів. Досліджено способи застосування техніки дротарства та концепції створення арт-об'єктів шляхом надання твору власного змістового складника, визначено творчі підходи до створення арт-об'єктів.

Наукова новизна полягає у дослідженні авторських художніх прийомів та особливостей створення об’єктів мистецтва ленд-арту з використанням техніки дротарства.

Практична значущість полягає у систематизації способів створення об'єктів ленд-арту, виконаних у техніці дротарства. Репрезентовані у статті матеріали можуть бути використані в наукових дослідженнях, присвячених мистецтву ленд-арт в Україні та світі, популяризації традиційних технік декоративно-ужиткового мистецтва, а також для подальшого впровадження в авторських мистецьких проєктах.
\end{abstract}

Ключові слова: дизайн, мистецтво, екологія, екодизайн, культура, творчі проєкти.

Introduction. Land Art originated in the second half of the 20th century; however, it has deep roots and a wide range of primary sources, among which the decorative and applied arts have an important place. To create their works, Land Art artists use natural materials, landscape elements, natural phenomena, and the environment. At the present stage, art history is aware of the need to study artistic techniques, technical means, and methods of creation of Land 
Art objects. The tendency to turn to the acquisition of artistic heritage can be explained by the use of traditional techniques as a source of deep historical and cultural traditions. In the modern art space of Ukraine and the world, the interest in traditional knowledge and historical heritage of ancestors is revived.

Artists use traditional techniques to realize their works in combination with modern technologies. Artists and designers widely use the elements of eco-style in their creative projects because they combine the philosophy of environmentally friendly natural material, the environment in which the work is presented, and the experience gained by the masters. Artists use the traditions of decorative and applied art as an appeal to folk art, ethnic motifs as a source of inspiration, namely: the use of stylistic, partially decorative, as well as formative techniques of folk art and crafts in Land Art objects. During the realization of creative ideas, Land Art artists resort to various traditional techniques, namely: weaving from the vine, weaving from the cat's tails, wire-weaving, carving, stonemasonry, etc. The relevance of the study of the wire-weaving technique is that it is widely used in the works of Land Art artists in Ukraine and the world and has not been fully studied yet.

Main part. In our days, comprehensive studies of Land Art, its importance, and use in the field of culture and art are conducted in Ukraine and around the world and presented in the scientific literature. The authors (Galchynska et al., 2019) have analyzed the works of the leading Land Art artists. For example, (Pico, 2019) in his publication focuses on the study of Land Art works from the air. A. Rigaud's study (Rigaud, 2012) is devoted to American Land Art and its geography.

Also, the research of various directions of design is carried out; in particular, I. Sivash (Sivash, 2018) studies the conceptual bases of ethno-design in Ukraine. The principles of application of weaving techniques in Land Art are studied by the authors (Galchynska et al., 2020). The role of installation in the subject environment is examined by B. Hinkes (Hinkes, 2017). The aesthetics of the subject environment is studied by A. Berleant, A. Carlson (Berleant, Carlson, 2007) and K. Porada (Porada, 2018). The basic concepts and creative approaches, as well as the materials from which the works are made, are presented at the personal webresources of the artists. Also, the materials, techniques, and creative achievements that belong to an international heritage are demonstrated at the UNESCO website (United Nations Educational, Scientific and Cultural Organization, 2019).

Despite the wide coverage of the researched problem by different authors, the question is at the initial stage of its study; the creative approaches of the artists and the variety of traditional techniques are constantly supplemented by new aspects. Thus, the use of the techniques of decorative and applied arts to create Land Art objects needs further research.

The purpose of the research is to analyze the use of the wire-weaving technique in the creation of Land Art objects and to determine the creative techniques used by the artists in their work.

Results of the research. Among the Land Art artists, it is very popular to use the wire-weaving technique - that is, weaving from metal wire. The term "wire-weaving" comes from the German "draht" - wire (Heiko, 2013: 72). Wire-weaving originated and spread in Slovakia at the beginning of the 17th century, and in the 19th century, it was widespread among the artisans. The reasons for the emergence and spread of the technique are considered to be the emergence of the steel industry and plants for the production of metal wire in eastern Slovakia. Starting from the second half of the 19th century and till the beginning of the 20th century, wire-weaving was widely used in Central and Eastern Europe by the following nations: Germans, Austrians, Czechs, Slovaks, Poles, Romanians, Lithuanians, Bulgarians, Hungarians, Russians, Belarusians, and others.

In Ukraine, this folk craft was more popular in the West (current Ivano-Frankivsk, Zakarpattia, Lviv, Chernivtsi, Volyn, and other regions). The wire-weaving has arisen as a way to repair ceramics. Wire-weavers twined cracked or broken jugs all around with metal wire (Fig. 1).

Later, using wire-weaving, the craftsmen began to create a variety of products and household items: nets, birdcages, flower boxes, furniture, stands, hooks, hangers, lampshades, baskets, sifters, trays, cup holders, and other necessary items. In 2019, Slovakia's wire-weaving was included in the UNESCO List of Intangible Cultural Heritage (United Nations Educational, Scientific and Cultural Organization, 2019). Wire-weaving is widely used by modern artists of decorative and applied arts to create furniture, household items, jewelry, etc. (table 1).

In modern art, the use of the wire-weaving technique is popular, because this technique allows creating three-dimensional, strong, plastic items since the wire is more flexible than natural materials and it is easy to work with it. When creating art objects, the artists apply a variety of methods and techniques of using wire, in particular:

- modeling of three-dimensional works made from a continuous wire by wrapping several layers of material (Fig. 2, c; Fig. 3);

- creation of three-dimensional plastic sculptures made from wire mesh (Fig. 2);

- welding of individual fragments from the wire of various thickness (Fig. 5, c);

- combination of the wire with other materials (wood, stones, glass, metal, lighting equipment, etc.) (Fig. 4, b; Fig. 5);

- use of colored wire or recycled wire (Fig. 3; Fig. 4, b).

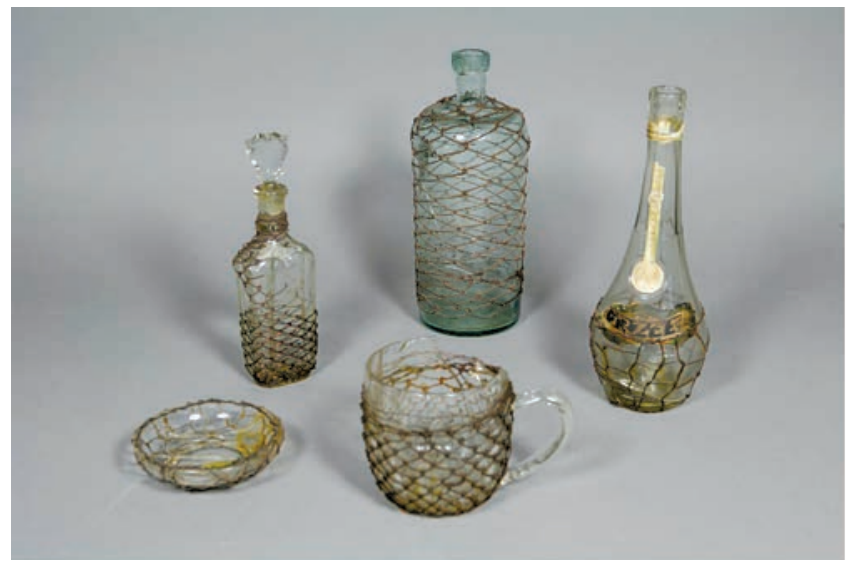

Fig. 1. Samples of traditional wire-weaving of tableware. National Museum-Reserve of Ukrainian Pottery in Opishne 
Table 1

Decorative and applied products made by means of the wire-weaving technique

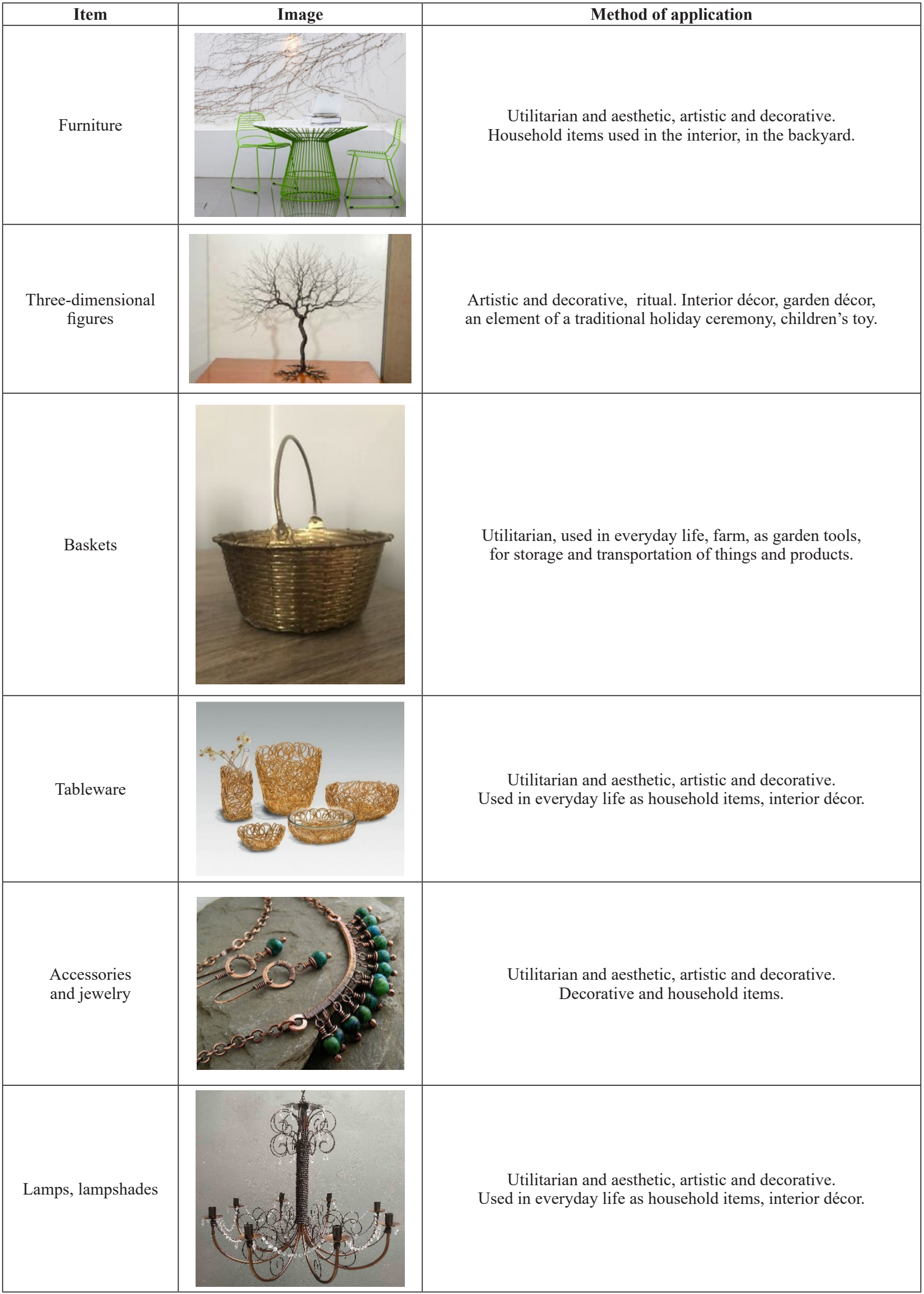


Kendra Heist, a British artist (Haste, n.d.), uses wire mesh in her works. She recreates anamorphic sculptures from rolled galvanized wire using the plasticity of the material for a detailed anatomical analysis of animal figures. Due to the plasticity of the material, the author conveys the smallest details of the image, as well as the movement, gaze, emotion of embodied animals. Her composition Family of Baboons (Chacma babon trop) (private collection, the UK, 2018) consists of five life-sized figures of baboons, which organically fit into the estate location, where they are located on the roof of the building, imitating the movements and mannerisms of primates (Fig. 2, a). The wireweaving technique allows introducing the figures of baboons in the smallest details, their hairstyles, and to convey the anatomy of the toes. The sculptural composition Stalking Lioness and Male Lion (Tower, London, the UK, 2010) embodies a powerful emotional play of life-sized figures of a lion and a lioness; the power and strength of predators are embedded in their images (Fig. 2, b). This art object recreates the texture of a disheveled lion's mane, realistically recreates muscles, and the tense movements of animals are demonstrated due to the plasticity of the material.

The wire-weaving technique occupies an important place in the works of Land Art artists as it is easy in use and combination with other materials. Robin Wight, a British artist, creates various anthropo- and floromorphic images from a continuous wire, mainly flowers and mythical characters; also, he is the founder of the FantasyWire design brand (Wight, n.d.). The artist's art objects are distinguished by their plasticity, dynamics, and attention to details, for the creation of which the author uses different techniques: the wings of fairies are made from a thin wire, woven like openwork lace; figures are made from a strong thick woven wire that models anatomic forms of the body; hair is made from a long, sometimes colored wire, which is curled in individual volumes and imitates the texture of real hair. His the most popular work is Fairy Trail, which is located in the natural park Trentham Gardens (Staffordshire, the UK, 2014) and includes 15 figures of fairies 2-5 $\mathrm{m}$ in high, which are installed along the trail and inscribed in its picturesque landscapes. The trail is designed to show to the visitors the art objects located among various locations of the park. His fairies seemed to be frozen in weightless motion, flying, jumping, or playing with the dandelion and its inflorescences, which seemed to swell and fly away, giving the visitors some mystical impression. The main concept of Robin Wight's works is to make the visitor get into a fairy tale, using the image of the art object, its surroundings, the sun's rays, which changes the angle of illumination during the day, each time showing the works in a different light.

One of such works is Skylark (Staffordshire, the UK, 2014) (Fig. 2, c). Land Art is a fairy playing with dandelion and shaking down the inflorescences. The author paid great attention to details of the work, using various techniques, reproducing the figure of a fairy and a dandelion. He contrasts the massive volumes of a dandelion and the figure of a fairy to the light, delicate, weightless wings and dandelion inflorescences.

Over 10 years, Robin Wight embodied several art projects, created about a hundred bright, dynamic works of Land Art from wire, which are popular among more than 4 million peoples (Wight, n.d.).

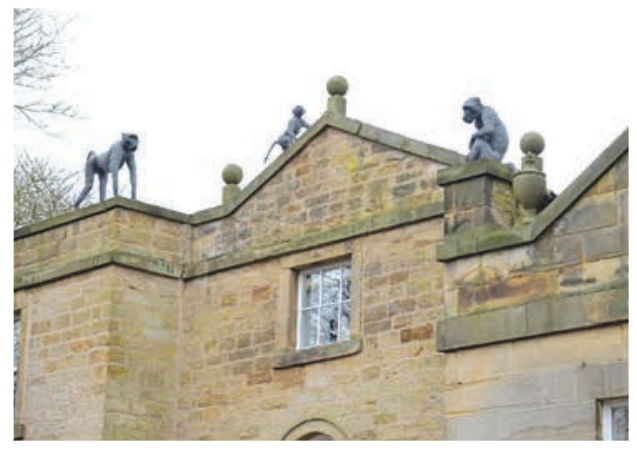

$\mathrm{a}$

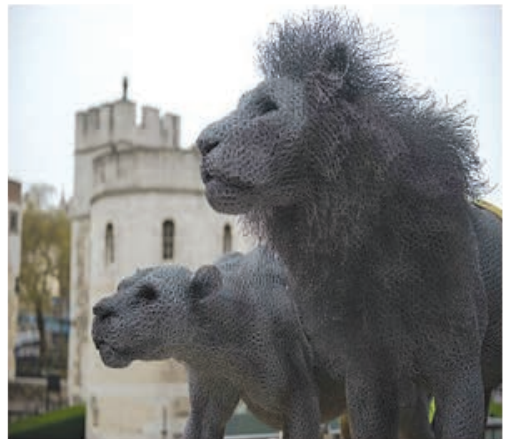

b

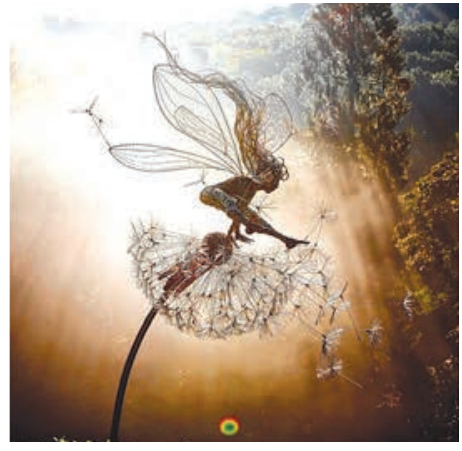

$\mathrm{C}$

Fig. 2. The ways to use the wire-weaving technique:

a - Family of Baboons by Kendra Heist, private collection, the UK, 2018; b - Stalking Lioness and Male Lion by Kendra Heist, London, the UK, 2010; c - Skylark by Robin Wight, Staffordshire, the UK, 2014

David Vanorbeek, a Belgian artist, has a completely different approach to the creation of projects; he uses the wireweaving technique, creating Land Art objects and providing the works with conceptual significance. The author's creative works include large, shaped compositions with animalistic figures of ants, mantises, bees, as well as a lot of abstract works with environmental content. David Vanorbeek creates his sculptures from used wire, that is why these works are also examples of recycling art. His Land Art Ants is a permanent exhibition in the Park of Sculpture Chateau de Lagravade (Agen, France, 2016) (Fig. 3, a). This project embodies realistic images of a group of giant ants $150 \mathrm{~cm}$ high each, made from metal wire and scrap metal, and located in a field in the middle of the landscape of the French countryside, which shows the everyday life of ants, reproducing their movement and behavior. The concept of the work is to provide the insects with an exaggerated image to demonstrate to humanity who are the real masters of the planet. At the same time, David Vanorbeek used another approach to the realization of images in his composition The 4 Elements (size $2 \times 2.5 \mathrm{~m}$ ). It is a permanent exhibition in the Park of Sculpture Chateau de Lagravade, Agen, France, 2016 (Fig. 3, b). This Land Art object has abstract images of four elements: earth, water, 
fire, and air, which differ in shape and size but have common stylistic features (Vanorbeek, n.d.). The composition is exhibited in a field in the middle of grasses and demonstrates the fluidity of natural elements and their dominance over plants, the harvest and life of which depend on the variability of nature.

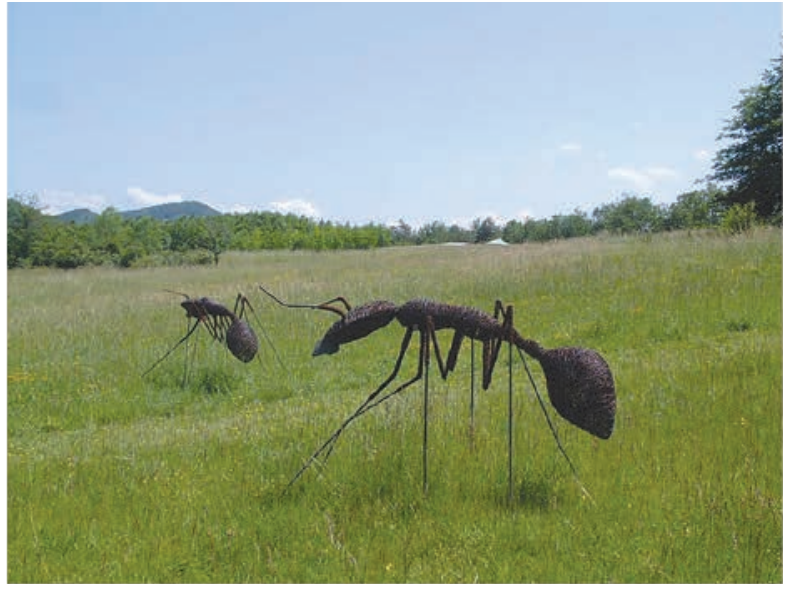

a

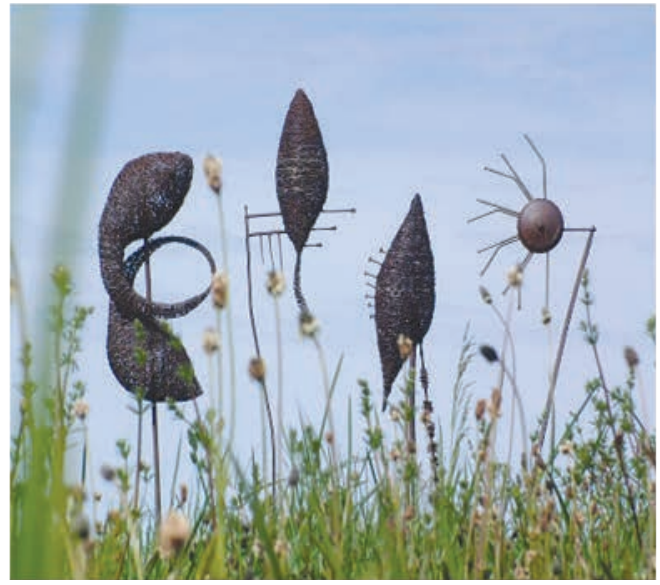

b

Fig. 3. Works of Land Art by David Vanorbeek: a - Ants, Agen, France, 2016; b - The 4 Elements, Agen, France, 2016

Among the Ukrainian artists who use the wire-weaving technique, there is a well-known creative duo of Oleksyi and Kyrylo Shevchuk, brothers, who established their own brand ARTBUZ and have a large collection of creative projects, among which Cavalier and Josephine, The Bull's Constellation, KRYSavtsi, KRYSyni, svitoZHABLI, vozDUKHOLAYTY, SVEToBUKET and many others (Shevchuk, 2020). The main material of their works is metal wire; they also use lighting elements and devices, thus transforming an art object into a unique designer lamp or creating a composition of various luminous elements.

Kyrylo Shevchuk's installation The Geometry of Shading (Kyiv, Ukraine, 2018) is a figurative composition of lacy figures of people who seem to be frozen in various poses (Fig. 4, a). The composition is made from metal wire, and due to the illumination at a certain angel, the figures reflect the amazing shadows on the surface of the objects next to them. The use of wire gives the general impression that the figures are made from a thin airy substance which in turn gives a sense of three-dimensionality, emphasized by the geometric shape of the sculptures, the play of light and shadow. The project embodies the visualization of thinking about space, time, infinite freedom, gravity, and the desire to fly, in which the author tries to understand the fundamental philosophical labyrinths of human life (Shevchuck, 2020).

The art object The Bull's Constellation, designed by Oleksyi Shevchuk (Kyiv, Ukraine, 2018) is an echo of the naive art of Ukrainian artist Maria Pryimachenko (Fig. 4, b). The author embodied the image of a bull from the painting Ukrayins'kyy polis 'kyy bychok-tretyachok hulyaye u lisi ta sylu zbyraye (Uktrainian Bull from Polissya Walks in the Woods and Gathers Strength), using several techniques in his work at the same time - elements wicked from wire are painted in colors used in Maria Pryimachenko's works to achieve recognizability of the work. The use of light bulbs reproduces the conceptual idea of O. Shevchuk - a constellation woven into the body of a bull. The work combines modern material and artistic concept with the authenticity of Ukrainian culture (Shevchuck, 2020).

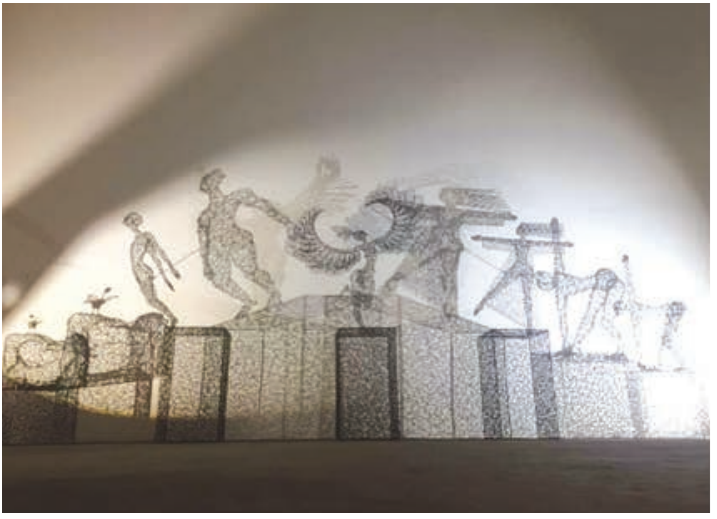

a

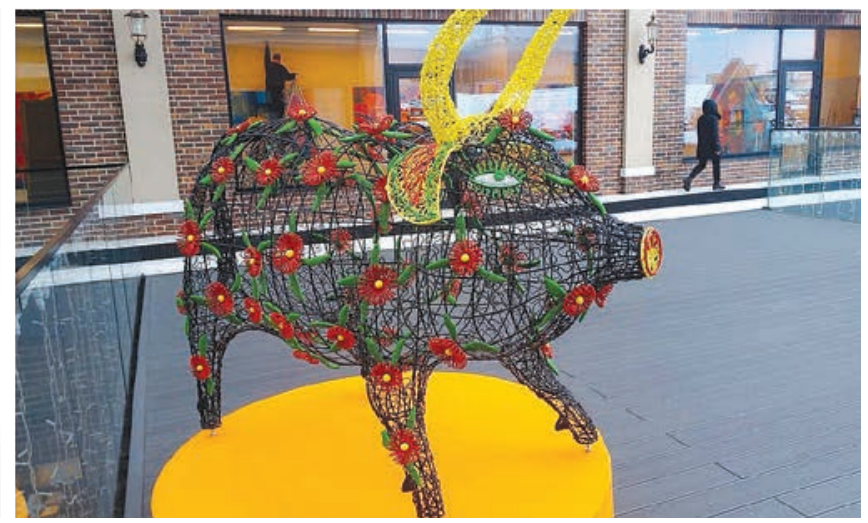

$\mathrm{b}$

Fig. 4. The conceptual works of the duo ARTBUZ: a - The Geometry of Shading by Kyrylo Shevchuk, Kyiv, Ukraine, 2018; b - The Bull's Constellation by Oleksyi Shevchuk, Kyiv, Ukraine, 2018 
Sometimes Land Art artists combine different materials using wire-weaving. For example, in O. Halchynska's Land Art object The Coluber, created at the festival Synergy (Hydropark, Kyiv, Ukraine, 2019), the wire-weaving technique is used to secure the wooden brushes from which the Land Art object is created (Fig. 5, a). The idea of the work is dedicated to the forest Coluber - a snake that lives in Ukraine is the largest in Europe, and now is on the verge of extinction thus listed in the Red book of Ukraine. The reasons for the Coluber's extinction are the change of the climate and human intervention in its habitats. That is why a Land Art object in the form of a Coluber was created on the territory of the Hydropark as a symbol of the disappearance of animals as a result of human activity. According to the artists, a Coluber curled up in a ring around the nest with eggs and raised his head to protect his offspring. The work is $16 \mathrm{~m}$ long and $1.5 \mathrm{~m}$ high. In this work The Coluber, the wire-weaving has a special constructive application, because the whole work was braided with wire to design the shape and secure the brushes, as well as to provide the work with strength and vandal resistance.

Korean artist Jae Hyo Lee uses the combination of natural stone found in nature and wire to create art objects (Lee, n.d.). The author changes the perception of the composition by creating three-dimensional geometric structures, where individual elements of the installation are hung up on wires, creating the effect of stones levitation, thus conquering the air by man. Working with different materials, such as stones, wood, metal, wire, and nails, the artist creates his interpretation of the world around him, presenting the essence of each material in a series of author's installations. Jae Hyo Lee's Land Art object 0121-1110=197073 (Seoul, Korea, 1997) is an installation created from unprocessed pieces of natural stone hung up on wires, which together form a huge ball that is fixed to a geometric metal construction (Fig. 5, b). In such a way the artist created the effect of levitating stones. The size of the work is $2.2 \mathrm{~m}$ wide, $2.2 \mathrm{~m}$ long and $3.5 \mathrm{~m}$ high. In this case, the wire has more functional than the formative component in contrast to Jae Hyo Lee's other work 0121-1110=109073 (Seoul, Korea, 2009), made from wire (Fig. 5, c). The artist created a composition, size $2.0 \times 2.15 \mathrm{~m}$, from three openwork dendromorphic objects, using the wire-weaving technique to reproduce the texture of small, weightless, transparent wooden brushes. The art-object is created by welding the elements of wire of different thicknesses with a strong metal trunk.

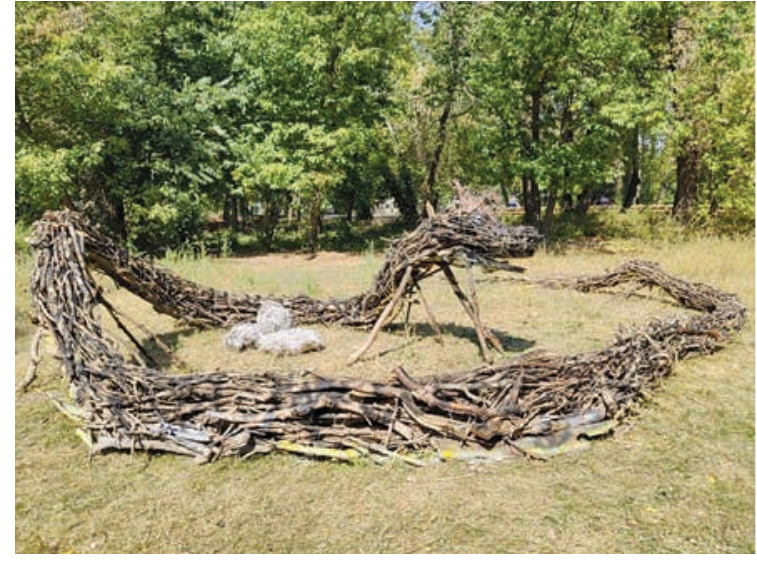

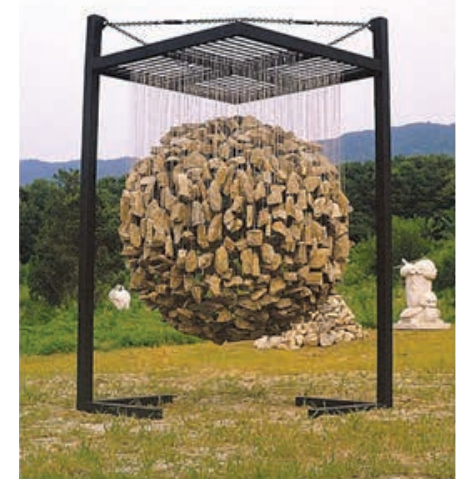

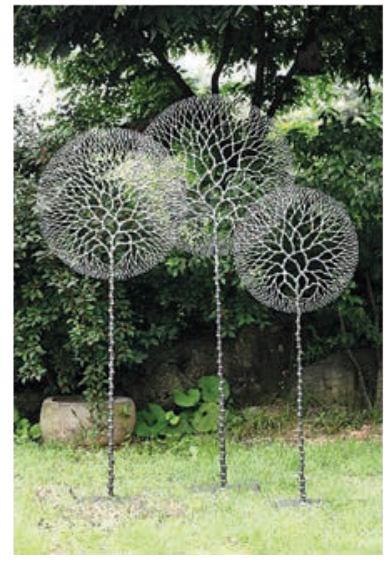

Fig. 5. The works of Land Art made by means of the wire-weaving technique:

a - The Coluber by O. Halchynska, Kyiv, Ukraine, 2019; b - 0121-1110=197073 by Jaehyo Lee, Seoul, Korea, 1997; c - 0121-1110=109073 by Jae Hyo Lee, Seoul, Korea, 2009

Therefore, the works of Land Art made by means of the wire-weaving technique can be classified according to the following factors:

- by morphological features: bionic forms (anthropo-, zoo-, dendro-, floromorphic, etc.), crystal-morphic forms (geometric, abstract, etc.);

- by size: large, medium, small;

- by the original form: continuous wire, wire mesh, pieces of wire of different thickness and length, etc.;

- by the type of outer surface of the wire: polished, facetted, etched, with metallic or non-metallic coating, heattreated, scaled, etc.;

- by the way of creation of visual effects: weaving, twisting, creating a frame, braiding, winding, etc.;

- by technique: flattening, fastening, soldering, forging, riveting, etc.

Summing up all the above, we can say that the methods of using the wire-weaving technique provide Land Art artists with a lot of opportunities, in particular, they can provide the plasticity to art objects, present fine detailing of works, use various textures in their works, combine different materials, provide the works with artistic expressiveness, etc.

Conclusions. The wire-weaving technique used by the artists in the creation of Land Art objects is studied. It is determined that wire-weaving has a lot of advantages for demonstration of the visual effects of works, namely: plasticity of the material, durability, vandal resistance, texture, etc. Techniques and methods of creation of Land Art objects, made by means of the wire-weaving technique, are classified. The analysis of the methods of using wire, 
used by the artists to embody the works of Land Art, is carried out. It is determined that the creators of Land Art while using the wire-weaving technique promote not only the art and philosophy of Land Art but also the ethnographic culture of their country. The prospects for further research into the Land Art are aimed at studying other traditional techniques used by the artists in their practice.

\section{Bibliography:}

1. Гальчинська О.С., Гамалія К.О., Пашкевич К.Л. Аналіз творчості провідних митців ленд-арту XX століття. Art and design. 2019. № 3. C. 48-57. DOI: https://doi.org/10.30857/2617-0272.2019.3.5.

2. Гальчинская О., Васильева Е., Пашкевич К. Использование техники плетения из природных материалов в искусстве ленд-арт. Revista de științe socioumane. Chişinău. 2020. № 1(44). C. 95-106. URL: https://ibn.idsi.md/vizualizare_ articol/109949.

3. Pico R. Aerial art, the new landscape of Robert Smitson. Journal of Architecture and Urbanism. 2019. Volume 43 Issue 2. C. 181-191. DOI: https://doi.org/10.3846/jau.2019.10354.

4. Rigaud A. Disorienting Geographies: Land Art and the American Myth of Discovery. Miranda. 2012. Vol: 6. DOI: https://doi.org/10.4000/miranda.2955.

5. Porada K. Land Art in Public Spaces Design: Remediation, Prevention of Environmental Risks and Recycling as a Consequence of the Avant-Garde Activity of Landscape Architecture. World Academy of Science, Engineering and Technology International Journal of Architectural and Environmental Engineering. 2018. Vol. 12, No. 10. Pp. 987-993. DOI: doi.org/10.5281/ zenodo.1474887.

6. Сиваш I.О. Концептуальні засади етнодизайну в Україні. Вісник НАККIM. 2018. № 3. С. $416-420$. URL: http://nbuv.gov.ua/UJRN/vdakkkm_2018_3_81.

7. Гейко А. Ремонт глиняного посуду. Історія, традиції, звичаї : монографія. Полтава. ТОВ «АСМІ». 2013.177 с.

8. Hinkes B. Approaching Aisthetics Or: Installation Art and Environmental Aesthetics as Investigative Activity. Espes. 2017. Vol. 6. No. 2. Pp. 62-71. URL: https://espes.ff.unipo.sk/index.php/ESPES/article/view/96.

9. Berleant A., Carlson A. The aesthetics of Human Environments. Broadview press. 2007. P. 312.

10. United Nations Educational, Scientific and Cultural Organization. 15 cultural practices join UNESCO's Representative List of Intangible Heritage. 2019, Dec 12. URL: 15 cultural practices join UNESCO's Representative List of Intangible Heritage.

11. Haste K. Kendra Haste Works. URL: https://www.patrickdaviesca.com/artists/kendra-haste-mrss/3/works/ (Last accessed: 15.01.2021).

12. Vanorbeek D. Metal Art Sculptures. URL: https://www.vanorbeek.com/sculpture-figurative/(Last accessed: 15.01.2021).

13. Шевчук Олексій. (особисте спілкування 25.02.2020).

14. Шевчук Кирило. (особисте спілкування 25.02.2020).

15. Lee J.H. Gallery. URL: http://www.leeart.name/board/bbs/board.php?bo_table=stone (Last accessed: 15.01.2021).

16. Wight R. Fairies. URL: https://www.fantasywire.co.uk/fairies/ (Last accessed: 15.01.2021).

\section{References:}

1. Halchynska, O.S., Hamaliia, K.O., Pashkevych, K.L. (2019). Analiz tvorchosti providnykh myttsiv lend-artu XX stolittia [Analysis of the creativity of the leading artists of Land art of the twentieth century]. Art and design. No. 3. P. 48-57. DOI: https://doi.org/10.30857/2617-0272.2019.3.5 [in Ukrainian].

2. Gal'chinskaja, O., Vasil'eva, E., Pashkevich, K. (2020). Ispol'zovanie tehniki pletenija iz prirodnyh materialov v iskusstve lend-art [Using the technique of weaving from natural materials in the art of Land art]. Revista de științe socioumane. No. 1(44). P. 95-106. Retrieved from: https://ibn.idsi.md/vizualizare_articol/109949 [in Russian].

3. Pico, R. (2019). Aerial art, the new landscape of Robert Smitson. Journal of Architecture and Urbanism. Volume 43. Issue 2. P. 181-191. DOI: https://doi.org/10.3846/jau.2019.10354.

4. Rigaud, A. (2012). Disorienting Geographies: Land Art and the American Myth of Discovery. Miranda. Vol. 6. P. 1-15. DOI: https://doi.org/10.4000/miranda.2955.

5. Porada, K. (2018). Land Art in Public Spaces Design: Remediation, Prevention of Environmental Risks and Recycling as a Consequence of the Avant-Garde Activity of Landscape Architecture. World Academy of Science, Engineering and Technology International Journal of Architectural and Environmental Engineering. Vol.12, No. 10. P. 987-993. DOI: doi.org/10.5281/ zenodo.1474887.

6. Syvash, I.O. (2018). Kontseptualni zasady etnodyzainu v Ukraini [Conceptual principles of ethnic design in Ukraine]. Visnyk NAKKIM. No. 3. P. 416-420. URL: http://nbuv.gov.ua/UJRN/vdakkkm_2018_3_81 [in Ukrainian].

7. Heiko, A. (2013). Remont hlynianoho posudu. Istoriia, tradytsii, zvychāi [History, traditions, customs]. TOV "ASMI". 177 p. [in Ukrainian].

8. Hinkes, B. (2017). Approaching Aisthetics Or: Installation Art and Environmental Aesthetics as Investigative Activity. Espes. Vol. 6. No. 2. P. 62-71. Retrieved from: https://espes.ff.unipo.sk/index.php/ESPES/article/view/96.

9. Berleant, A., Carlson, A. (2007). The aesthetics of Human Environments. Broadview press. P. 312.

10. United Nations Educational, Scientific and Cultural Organization. (2019, Dec 12). 15 cultural practices join UNESCO's Representative List of Intangible Heritage. URL: 15 cultural practices join UNESCO's Representative List of Intangible Heritage.

11. Haste, K. (n.d.). Kendra Haste Works. Retrieved from: https://www.patrickdaviesca.com/artists/kendra-haste-mrss/3/works/.

12. Vanorbeek D. (n.d.). Metal Art Sculptures. Retrieved from: https://www.vanorbeek.com/sculpture-figurative/.

13. O. Shevchuck (personal communication, February 25, 2020).

14. K. Shevchuck (personal communication, February 25, 2020).

15. Lee, J.H. (n.d.). Gallery. Retrieved from: http://www.leeart.name/board/bbs/board.php?bo_table=stone.

16. Wight, R. (n.d.). Fairies. Retrieved from: https://www.fantasywire.co.uk/fairies/. 